УДК 636.4.082

(C) 2012

Бірта Г. О., доктор сільськогосподарських наук,

Бургу Ю. Г., кандидат сільськогосподарських наук

Вищий навчальний заклад Укоопспілки «Полтавський університет економіки і торгівлі»

\title{
ФОРМУВАННЯ М'ЯСО-САЛЬНОЇ ПРОДУКТИВНОСТІ РІЗНИХ ГЕНОТИПІВ СВИНЕЙ
}

\section{Рецензент - доктор сільськогосподарських наук, професор В. П. Рибалко}

Відгодівля і м'ясна продуктивність тварин обумовлюється їх генотипом і середовищем. Під впливом спадкових якостей і умов середовища розвиток тварин проходить неоднаково: на різних фізіологічних стадіях свого розвитку їх темпи формування різні. Вони в значній мірі залежать від інтенсивності обміну речовин в організмі. У впливі генетичних і паратипічних факторів на окремі господарсько корисні ознаки простежується чітка закономірність, яка виражається в наступному: чим більша сила впливу паратипових факторів, тим вища ступінь взаємодї̈ генотипу й середовищза. Співвідношення м'язової, жирової та кісткової тканин при забої свиней визначаються не лише віком, статтю, величиною кінцевої живої маси на етапі завершення відгодівлі, типом відгодівлі, а й напрямом їх продуктивності та племінною роботою.

Ключові слова: жива маса, генотип, відгодівля, рівень годівлі, середньодобові прирости, затрати корму, свинки, кастрати, кнуриі, шпик, м'ясо, забійні якості.

Постановка проблеми. На формування м'ясо-сальних якостей свиней впливає багато чинників. Селекція на м'ясність - провідна ознака практично для всіх основних порід у країнах iз розвинутим свинарством.

Повноцінна годівля $є$ необхідною умовою підвищення індивідуальної продуктивності сільськогосподарських тварин, а остання визначає зоотехнічну та економічну ефективність ведення тваринництва.

Потреба тварин у протеїні залежить передусім від їх віку. Виділяють наступні періоди у вирощуванні й відгодівлі свиней, що пов'язані з інтенсивністю розвитку їх м'язових волокном: швидкого росту (приблизно до 80 днів), коли волокна найдовшого м'яза спини збільшуються більше ніж на 50 \%, що здійснюється в основному за рахунок розвитку м'язової тканини; перехідний (80-120 днів) характерний сталістю відкладання білку в тілі, уповільненням росту м'язових волокон і підвищенням інтенсивності процесів жироутворення; ожиріння, коли ріст м'язових волокон на 75 \% закінчений, відносний вміст білка в тілі починає падати, а кількість жиру збільшується майже прямолінійно.

Слід зауважити, що здатність утворення м'язових тканин, а також потреба тварин у протеїні, тісно пов'язана з їх спадковими задатками: за рівних умов годівлі та утримання тварини м'ясних порід більш інтенсивно синтезують білок, аніж сальних і напівсальних.

Аналіз основних досліджень і публікацій, у яких започатковано розв'язання проблеми. Підвищення м'ясності туш свиней шляхом спрямованої годівлі широко використовується в практиці свинарства. Проте не слід забувати: вміст м'яса в туші залежить також від факторів, що належать до спадковості (порода або породність, племінні якості та ін.).

Значним резервом збільшення виробництва свинини є підвищена передзабійна маса тварин. Однак, залишається до кінця не вирішеним питання про оптимальні кондиції свиней для забою. Дослідження показали, що відгодівля свиней до великих кондицій (120-130 кг) призводять до збільшення затрат корму на одиницю приросту й підвищення собівартості продукції. Збільшення кінцевої живої маси при відгодівлі від 100 до 125 кг (особливо до 150 кг) супроводжується природним подовженням часу і помітним зростанням кормових витрат та інших засобів на одиницю приросту. Більш м'ясні туші можна одержати від помісей (батьківські форми яких є м'ясні генотипи) при відгодівлі до 100125 кг, більш жирні - до 150 кг [2].

Підвищення забійної маси свиней до 110-120 кг дає змогу збільшити виробництво свинини в переліку на одну матку та знизити іiі собівартість. Забій свиней при нижчих вагових кондиціях сприяє зниженню кормових затрат і збільшенню виробництва м'ясних туш. Економічно це більш виправдано, особливо за інтенсивних технологій відтворення молодняку. Одночасно зі збільшенням живої маси свиней при забої від 100 до 140 кг відносна кількість м'яса в тушах знижується 3 
55,9 до 51,0 \%, а кількість жиру збільшується 3 27,4 до 33,5 \%. При цьому частка високоякісних м'ясних частин у тушах зменшується до $42,1 \%$, що суттєво впливає на їх класність і ціну на свинину. Фізико-хімічні дослідження якості м'яса й сала свиней з урахуванням віку свідчать про збільшення відсотка внутрішньом'язового жиру та сухої речовини в м'ясі, підвищення вмісту вологи і поліненасичених кислот у салі [4].

Результати наукових розробок свідчать, що м'ясну свинину як високоякісний продукт можна одержати із туш молодняку, інтенсивно відгодованого до 90-100 кг живої маси (при середньодобових приростах 600 г і більше, витраті на 1 кг приросту не більше 4 корм. од.). При цьому забезпечується вихід 55-58 \% м'яса без кісток і не більше 28-32 \% жиру при середній товщині шпику на спині 2,8-3 см. Саме така свинина найбільше відповідає вимогам м'ясопереробної промисловості та споживача. Одержати свиней із максимальною м'ясністю туш можна, передусім, шляхом систематичної селекції за цією ознакою. Велике значення при проведенні селекції на м'ясність має знання методів оцінки м'ясо-сальних якостей свиней [3].

Численими дослідженнями встановлено, що середній показник товщини шпику тісно взаємопов'язаний із вмістом м'яса та сала в туші свиней [1]. За вирівняністю хребтового сала можна робити висновки про м'ясо-сальні якості туш.

Мета досліджень і методика їх проведення. Дослідження проводилася на чистопородному свинопоголів'ї великої білої породи (ВБ) - I група, миргородської породи (М) - II група, полтавської м'ясної породи (ПМ) - III група, породи ландрас (Л) - IV група та червонопоясної спеціалізованої лінії (ЧПСЛ) - V група.

Відгодівельні якості молодняку вивчали за такими показниками:

- середньодобовий приріст за період відгодівлі, г;

- вік досягнення тваринами живої маси 100 i 125 кг, дні;

- затрати корму на 1 кг приросту, корм. од.

Забійні й м'ясо-сальні якості тварин визначалися за наступними показниками: передзабійна маса, кг; забійна маса, кг; забійний вихід, \%; довжина напівтуші, см; товщина шпику, мм; площа «м'язового вічка», см²; вихід м'яса і сала в туші, кг і \%.

Морфологічний склад туш вивчали шляхом обвалки правої напівтуші. Масу м'язової тканини визначали за різницею між масою напівтуші й сумарної маси сала та кісток. Площу «м'язового вічка» вимірювали на поперековому розрізі найдовшого м'яза спини, між останнім грудним і першим поперековим хребцями, методом копіювання «малюнка зрубу» на кальку та вимірювання його за допомогою планіметра.

Результати досліджень. При відгодівлі свиней за раціонами, типовими для багатьох господарств, живої маси 100 кг піддослідні тварини в середньому досягли за 350,8 днів при середньодобових приростах 289,4 г та затраті на 1 кг приросту 7,46 корм. од. корму. Кращими за відгодівельними якостями були тварини м'ясних генотипів. За віком досягнення 100 кг піддослідні тварини розподілилися за наступною послідовністю: ландрас (344,9 днів), полтавська м'ясна (346,7 днів), червонопоясна спеціалізована лінія (347,5 днів), велика біла (352,8 днів), миргородська $(362,1$ днів). Найменше витрачали корму на 1кг приросту підсвинки ЧПСЛ (7,31 корм. од.), найбільше (7,60 корм. од) - тварини миргородської породи, що слід пояснити інтенсивнішим відкладенням жирової тканини в їх організмі.

Що ж до статевої належності, то за всіма генотипами найкращі показники одержані по кастратах, на другому місці виявилися кнурці й на третьому - свинки, що пояснюється проявленням біологічних особливостей їх організму в процесі росту й розвитку.

Живої маси 125 кг піддослідні тварини в середньому досягли за 434,4 днів, при середньодобових приростах 291,3 г і затраті 8,67 корм. од. на кожний кілограм приросту. Слід підкреслити, що закономірність встановлена при відгодівлі тварин до 100 кг в основному мала місце й при відгодівлі до 125 кг живої маси; при цьому збільшилася затрата кормів на 1кг приросту на 1,21 корм. од., що можна пояснити збільшенням відкладання жирової тканини в тілі піддослідного молодняку.

При середньому рівні годівлі (середньодобові прирости 600-800 г) живої маси 100 кг піддослідні тварини в середньому досягли вже за 211,1 днів при середньодобових приростах 689,6 і затраті на 1 кг приросту 4,42 корм. од. Серед п'яти генотипів найкращими по віку досягнення живої маси 100 кг були тварини червонопоясної спеціалізованої лінії (205,7 днів). Вони мали також найвищі середньодобові прирости на відгодівлі $(712,7$ г) і найменше (4,30 корм. од.) витрачали кормів на одиницю приросту. П'яте місце посідали тварини миргородської породи: 655,7 г середньодобовий приріст, 219,9 днів - вік досягнення 100 кг при затраті 4,58 корм. од. на 1 кг приросту. Що ж до статевої належності, то найкращими показниками характеризувалися каст- 
рати всіх генотипів. Вони живої маси 100 кг досягали за 202,7-214,1 днів, свинки - за 208,3226,9 днів і кнурці - за 204,9-218,7 днів.

Живої маси 125 кг піддослідні тварини досягли в середньому за 242,3 днів при середньодобових приростах 711,1 г і затраті на 1 кг росту 4,54 кормової одиниці. Кращими 3-поміж генотипів виявилися тварини полтавської м'ясної породи. Порівняно з середніми показниками вони мали на 27,9 г краще середньодобовий приріст, раніше на 7,7 днів досягли живої маси 125 кг і менше на 0,08 корм. од. витрачали кормів на 1кг приросту. Як при відгодівлі до 100 кг, так і до 125 кг кращими показниками за відгодівельними якостями характеризувалися кастровані підсвинки.

Результати забою молодняку дозволили встановити характер впливу генотипового та паратипового факторів на забійні якості тварин.

Контрольний забій піддослідних підсвинків першої серії дослідів при середньодобових приpocтах 250-350 г показав, що тварини м'ясних генотипів (III, IV, V груп) мали явні переваги в порівнянні з аналогами I та II груп.

Найвищі показники забійного виходу мали тварини полтавської м'ясної породи і ландрас: відповідно, 70,9 і 70,7 \% при 100 кг і 71,6-72,1 \% при 125 кг. Вони переважали тварин миргородської породи на 2,7-2,9 \% при забої в 100 кг і на 2,4-2,9 \% - в 125 кг. Довжина півтуші виявилася стабільною типовою ознакою і залежала від генотипу піддослідних тварин. Найдовшими були туші породи ландрас: у межах 96,0-100,0 см, а найкоротшими - миргородської породи - 91,993,4 см. Найбільша товщина шпику відмічалась у молодняку II групи (38,5 мм у 100 кг та 42,8 мм 125 кг).

За масою задньої третини півтуші найкращі показники мали тварини III піддослідної групи. У них вона при забої у 100 кг становила 12,1 кг; збільшення живої маси призвело до збільшення маси окосту по групах у середньому на 1,5 кг.

Отримані дані стосовно статевої різниці підтведили результати інших дослідників: кастрати не поступалися свинкам за довжиною туші, масою окосту; туші кастратів характеризувалися дещо більшою товщиною шпику.

Позитивний вплив статевих гормонів на м'ясність туш проявився у свиней усіх порід: кнурці в порівнянні 3 кастратами мали довші туші й меншу товщину шпику. Збільшення середньодобових приростів привело до покращання забійних якостей. При цьому тенденція до отримання кращих забійних якостей $\mathrm{y}$ тварин м'ясних генотипів збереглась і стала більш суттєвою.

Свині породи ландрас були найдовшими і мали найбільший забійний вихід та масу окосту. Майже не поступались їм свині полтавської м'ясної породи. Тварини червонопоясної спеціалізованої лінії мали найменшу товщину шпику 30,1-32,8 мм, що на 5,2-5,8 мм менше, ніж у миргородської породи, де цей показник виявився найбільшим.

Результати забою I серії досліджень за різних рівнів відгодівлі засвідчили перевагу м'ясних генотипів над представниками сальних i м'ясосальних порід за показниками забійного виходу, довжини півтуші, товщини шпику та маси окосту.

На основі одержаних експериментальних даних проведено дисперсійний аналіз впливу рівня годівлі на забійні якості свиней. Факторна дисперсія, що характеризує мінливість показника, викликану впливом годівлі, дорівнювала $0,72-$ 0,79 при забої в 100 кг і $0,71-0,85$ при забої в 125 кг. У середньому по досліду загальна дисперсія, що показує загальну мінливість ознаки, при забої свиней живою масою 100 кг коливалась від 0,93 у свиней миргородської породи до 1,01 - у полтавської м'ясної. Найбільшою частка впливу рівня годівлі на забійний вихід спостерігалась у свиней м'ясних генотипів, зокрема у полтавської м'ясної $(84,9-88,8$ \%) та червонопоясної спеціалізованої лінії м'ясних свиней $(86,4-$ $83,6 \%)$.

Як свідчать отримані результати дослідів, товщина шпику детермінована породними особливостями.

Середня товщина шпику по хребту при забої в 100 кг при середньодобових приростах 250-350 г знаходилась в усіх групах у межах 29,7-34,9 мм. При відгодівлі до 125 кг, відповідно, збільшувалась і середня товщина шпику по хребту. Так, у тварин мирогородської породи товщина збільшилася на 3,5 мм, а червонопоясної спеціалізованої лінії - на 2,5 мм.

При збільшенні середньодобових приростів до 600-800 г, середня товщина шпику в тушах дослідних свиней зменшувалася: при забої в 100 кг - у межах 29,1-34,0 мм.

У тушах свиней, забитих із живою масою 125 кг, середня товщина шпику дорівнювала 31,5-37,2 мм.

Результати обвалки туш піддослідних свиней свідчать, що морфологічний склад туші залежить від породних особливостей тварин. При середньодобових приростах 250-350 г за рахунок низьких приростів i, як правило, більшого при цьому осалення, вихід м'яса у тварин усіх 
піддослідних груп був низьким.

При цьому найбільший вихід м'яса мали тварини червонопоясної спеціалізованої лінії: при забої в 100 кг - 50,6 \%, при забої в 125 кг - 48,9\%.

Порівняно 3 миргородською породою, де цей показник був найменшим, різниця склала 3,3-3,1 \%. Натомість, сала в тушах найбільше містилось у свиней саме миргородської та великої білої порід, відповідно, 41,2-39,2 та 43,3-42,3 \%. У кількісному вигляді м'яса в тушах було на рівні 32,4-36,0 кг при забої в 100 кг і 39,8-43,9 кг при забої в 125 кг. Різниця в кількості кісток у тушах виявилася незначною. Коефіцієнт співвідношення сала до м'яса за рахунок сильного осалення туш був високим, особливо у тварин миргородської породи (0,87-0,95). Найменша кількість сала по відношенню до м'яса була у тварин породи ландрас і червонопоясної спеціалізованої лінії. При збільшенні середньодобових приростів до 600-800 г спостерігалося збільшення кількості м'яса в тушах. Так, у тушах свиней полтавської м'ясної породи, забитих живою масою 100 кг, було 44,1 кг м'яса, або 60,3\%; забитих живою масою 125 кг - 53,7 кг, або 59,1\%. Вихід сала в тушах - на рівні від 28,1-29,4 \% у червонопоясних свиней до 33,4-36,7 \% - у миргородських аналогів.

При збільшенні забійної маси до 125 кг питома маса кісток у тушах зменшувалась в усіх піддослідних групах на 0,3-0,6 \%. Відмічалося зменшення відношення сала до м'яса в межах 0,46-0,61 при забої в 100 кг і 0,49-0,70 - в 125 кг.

Дисперсійний аналіз впливу рівня годівлі на вміст м’яса в тушах показав, що коефіцієнт детермінації, тобто питома вага факторіальної дисперсії в загальній, найбільшим був у свиней породи ландрас $(0,893-0,896)$, що, відповідно, й визначило найбільшу залежність у показниках вмісту м'яса цих тварин від рівня годівлі. Найменше фактор годівлі впливав на вихід м'яса в тушах миргородської породи.

Площа «м’язового вічка» у тварин усіх піддослідних груп значно коливалася: за типового рівня годівлі від 23,1 до 29,2 см $^{2}-$ в 100 кг і від 24,7 до $31,6 \mathrm{~cm}^{2}-$ у 125 кг. При середньому рівні годівлі для більшості підсвинків площа «м'язового вічка» істотно збільшувалася: при забої в 100 кг вона дорівнювала від 27,2 см² у миргородської породи до $34,9 \mathrm{~cm}^{2}-$ у породи ландрас. При збільшенні забійної маси до 125 кг площа «м'язового вічка» в тушах цих порід склала, відповідно, 28,3 і 37,4 см². Відношення площі «м'язового вічка» до площі підшкірного сала, що прилягає до нього, як відомо, має назву індексу м'ясності. Він дає змогу визначити співвідношення м'яса та сала в туші. Саме індекс м'ясності був найбільшим у тварин м'ясних генотипів.

Спостерігалася пряма залежність між середньодобовими приростами піддослідних свиней та індексом м'ясності. Збільшення площі «м'язового вічка» в групах тварин, вирощених iз більш високими середньодобовими приростами, вело до збільшення індексу м'ясності. Що стосується міжпородних розбіжностей, то найбільший індекс м'ясності мали свині породи ландрас при всіх рівнях відгодівлі.

Індекс м'ясності туш більше одиниці спостерігався у свиней породи ландрас, полтавська м'ясна, червонопоясна спеціалізована лінія за середнього рівня годівлі. При середньодобових приростах 250-350 г індекс м'ясності в усіх групах був менше одиниці, що підтверджує отримані раніше дані.

Найвищою енергетичною цінністю характеризувалося м'ясо тварин м'ясо-сальних i сальних генотипів (I та II групи). При типовому рівні відгодівлі калорійність ї м'яса становила в середньому 134,9-135,8 ккал при забої у 100 кг і 141,5-144,2 ккал - у 125 кг, що, відповідно, на 8,1-9,0 та 11,1-13,8 ккал більше в порівнянні 3 представниками породи ландрас, де цей показник був найменшим. При збільшенні середньодобових приростів спостерігалося зменшення калорійності м’яса. Найменшою вона була у свиней, вирощених за інтенсивного рівня відгодівлі: 116,2-124,4 ккал при забої в 100 кг і 122,4135,2 ккал - при забої в 125 кг.

Найбільша залежність індексу м'ясності від годівлі спостерігалась у свиней червонопоясної спеціалізованої лінії як при забої в 100, так і при забої в 125 кг (71,9-70,9\%). Індекс м'ясності туш свиней тварин мирогородської породи найменше залежав від рівня годівлі. Сумарна частка впливу цього показника при забої в 100 кг склала 49,5\%, у 125 кг - лише 44,8\%.

\section{Висновки:}

У процесі вивчення дії генетичних і паратипових факторів на окремі господарсько корисні ознаки тварин простежувалася чітка закономірність: чим більша сила впливу паратипових факторів, тим вище проявлявся ступінь взаємодії генотипу й середовища.

При відгодівлі свиней за раціонами, типовими для багатьох господарств, живої маси 100 кг піддослідні тварини в середньому досягли за 350,8 днів при середньодобових приростах 289,4 г та затраті на 1кг приросту 7,46 корм. од. корму. 
Кращими за відгодівельними якостями були тварини м'ясних генотипів, хоча ця різниця була несуттєвою. Збільшення середньодобових приростів на відгодівлі дало можливість виявити переваги м'ясних генотипів над великою білою і миргородською породами за середньодобовими приростами, витратами корму й часом досягнення необхідних забійних кондицій.

Контрольний забій виявив явні переваги тварин м'ясних генотипів у порівнянні з аналогами.

\section{БІБЛІОГРАФІЯ}

1. Акімов С. Співвідношення живої маси і товщини шпику / С. Акімов, А. Оксинюк // Тваринництво України. - 1994. - № 1. - С. 6.

2. Балла C. Оценка мясных качеств свиней/ С. Балла, Н. Бугаев. - М. : ВО Агропромиздат, 1988. - 72 c.

3. Диденко Л. А. Особенности формирования мясо-сальной продуктивности у свиней разных ге-
Найвищі показники забійного виходу мали тварини полтавської м'ясної породи і ландрас, як при 100 кг забійної маси, так і при 125 кг. Довжина півтуші виявилася стабільною типовою ознакою й залежала від генотипу піддослідних тварин. Що стосується статевої різниці, то кастрати не поступалися свинкам за довжиною туші, масою окосту; туші кастратів характеризувалися дещо більшою товщиною шпику.

нотипов / Л. А. Диденко, В. Е. Мазур // Актуальные вопросы обеспечения АПК : Тезисы докл. ХХ конф. молодых ученых - 1996. - С. 12.

4. Луценко В.A. Морфологический состав туш подсвинков асканийского типа украинской мясной породы / В. А. Луценко // Перспективы развития свиноводства : Материалы X межд. научно-произв. конф. - Гродно, 2003. - С. 66-68. 